Research Article

\title{
Analysis of Stability Factors of Roadway Roof and Determination of Unsupported Roof Distance
}

\author{
Sen Yang $(D)$, Xinzhu Hua, Xiao Liu $(\mathbb{D}$, and Chen Li $(\mathbb{D}$ \\ State Key Laboratory of Mining Response and Disaster Prevention and Control in Deep Coal Mines, \\ Anhui University of Science and Technology, Huainan 232001, Anhui, China
}

Correspondence should be addressed to Sen Yang; 1633234303@qq.com

Received 16 July 2021; Accepted 30 August 2021; Published 22 September 2021

Academic Editor: Shaofeng Wang

Copyright (c) 2021 Sen Yang et al. This is an open access article distributed under the Creative Commons Attribution License, which permits unrestricted use, distribution, and reproduction in any medium, provided the original work is properly cited.

To determine the impact of influencing factors on unsupported roof stability in coal mine roadway, a mechanical model of the unsupported roof was built. FLAC 3D numerical simulation was utilized to study the stability of the unsupported roof under the influence of the depth of the roadway, the thickness of the roof, and the unsupported-support distance. In view of the key influencing factors, the geological conditions of the site, and the relationship between the tensile stress and tensile strength of the unsupported roof, the maximum unsupported roof distance during roadway excavation was determined. Considering the surplus safety factor of the unsupported roof, the reasonable unsupported roof distance during the excavation of roadway 150802 was finally determined to be $2.08 \mathrm{~m}$. The comprehensive roadway excavation speed increased by $62.7 \%$, achieving a monthly progress over $500 \mathrm{~m}$.

\section{Introduction}

The speed of coal mine roadway excavation depends not only on the excavation equipment but also on the excavation process [1-4]. At present, most coal mine roadways are excavated with the traditional fully mechanized excavation equipment which repeatedly retreat $5 \mathrm{~m}$ from the roadwaying face for manual support operations. This back and forth roadwaying process puts a major limit to the excavation speed [5-7]. Increase in the coal mine roadway roadwaying speed can be achieved through two approaches, specifically: (1) increase the unsupported roof length and improve the efficiency of each roadway excavation cycle and (2) reduce the time consumption of roadway bolt support operation and increase the operating rate of the roadheader. A lot of research was carried out with both of the two approaches. Research on roadway support technology mainly focused on optimizing the roadway bolt (cable) support parameters to reduce the time consumption or increasing the frequency of single-shift cycle operations [8-12]. As for the length of the unsupported roof, Fan [13] analyzed the influence of roof area on the stability of the roadway through numerical calculation and determined the reasonable length of the unsupported roof. Ma [14] studied the rock beam of the unsupported roof with theoretical analysis, numerical simulation, field measurement, and other methods and analyzed the maximum unsupported roof length as well as the deformation and failure factors of the unsupported roof. $\mathrm{Wu}$ [15] studied the maximum length, deformation, and failure factors of the unsupported roof based on the plate mechanics model.

Although precious research studies have increased the speed of coal mine roadway excavation by a certain extent, the considered factors affecting unsupported roof stability were relatively limited. Therefore, a mechanical model was built to analyze the relationship between the tensile stress of the unsupported roof and the various influencing factors. Considering the site geological conditions, FLAC 3D numerical simulation software was used to simulate the influence of each factor on the stability of the unsupported roof. According to the determining conditions of roof stability and considering the surplus safety factor of the unsupported roof, a reasonable unsupported roof length during roadway excavation was finalized. In order to 
maximize the coal mine roadway roadwaying speed, the reasonable unsupported roof length was further optimized. On site results showed that the theory and numerical simulation analysis in this paper was safe and feasible for calculating the unsupported roof length. This paper also provides an important theoretical basis for rapid excavation of coal mine roadways.

\section{Mechanical Modeling of the Unsupported Roof}

Along with the roadway excavation, the pressure on the rock mass of the roadway surface goes from three-dimensional to two-dimensional while the strength of the rock mass reduces extensively. When the pressure exceeds the ultimate strength of the rock mass, the surrounding rock collapses, starting from the roadway surface which can be regarded as the direct roof. This collapse mainly occurs during the excavation cycle [16-18]. Therefore, the direct roof of the roadway is the key to the stability of the unsupported roof during the tunneling process.

In most cases, the roof is much thinner compared with the roadway width, and it can be regarded as a thin plate for the mechanical analysis $[19,20]$. The unsupported roof is supported by rock mass on the two sides, coal on the driving face, and roof bolts and cables at the rear. Therefore, some assumptions can be made for the unsupported roof: (1) the two sides and the driving face provide sufficient support for the unsupported roof while the roof bolts and cables provide relatively smaller support; (2) at the end of each cycle, the time span of the unsupported roof is short and the roof stability is good and can be regarded as a continuous and uniform medium; and (3) the unsupported roof is thin enough compared with the smallest characteristic dimension of the roof surface that it can be regarded as a thin plate.

Based on the assumptions above, a thin plate model with three fixed sides and one simply supported side is built, as shown in Figures 1 and 2. In Figure 1, $a$ is the width of the roadway, $b$ is the length of the unsupported roof, and $h$ is the thickness of the roof.

According to the thin plate theory $[21,22]$, the stress of a thin plate under the action of uniform load $q$ is as follows:

$$
\left\{\begin{array}{l}
\sigma_{x}=-\frac{8 \pi^{2} A E z}{a^{2}\left(1-\mu^{2}\right)}\left[\sin ^{2} \frac{\pi y}{b} \cos \frac{2 \pi x}{a}+\mu\left(\frac{a}{b}\right)^{2} \sin ^{2} \frac{\pi x}{a} \cos \frac{\pi y}{b}\right], \\
\sigma_{y}=-\frac{8 \pi^{2} A E z}{b^{2}\left(1-\mu^{2}\right)}\left[\sin ^{2} \frac{\pi x}{a} \cos \frac{2 \pi y}{b}+\mu\left(\frac{a}{b}\right)^{2} \sin ^{2} \frac{\pi y}{b} \cos \frac{\pi x}{a}\right], \\
\sigma_{z}=-\frac{4 \pi^{2} A E z}{a b(1+\mu)} \sin ^{2} \frac{2 \pi x}{a} \sin ^{2} \frac{2 \pi y}{b} .
\end{array}\right.
$$

In equation (1), $A=\left(q a^{2} / 4 \pi^{2} D\left[3+3(a / b)^{4}+2(a / b)^{2}\right]\right)$ and $D=\left(E h^{3} / 12\left(1-\mu^{2}\right)\right)$.

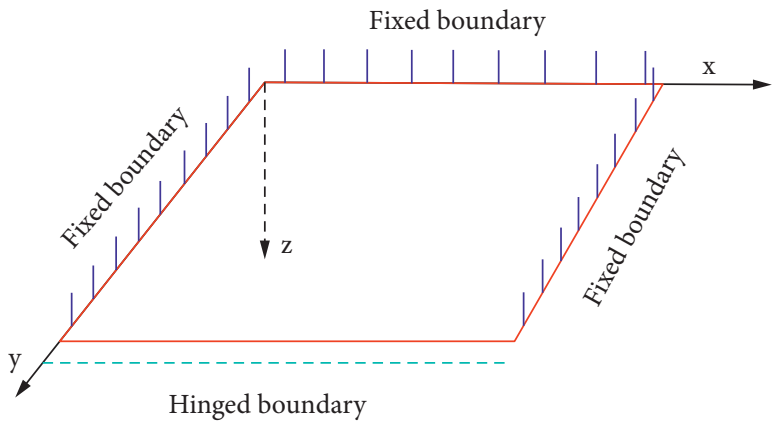

FIGURE 1: Working status of the unsupported roof boundary.

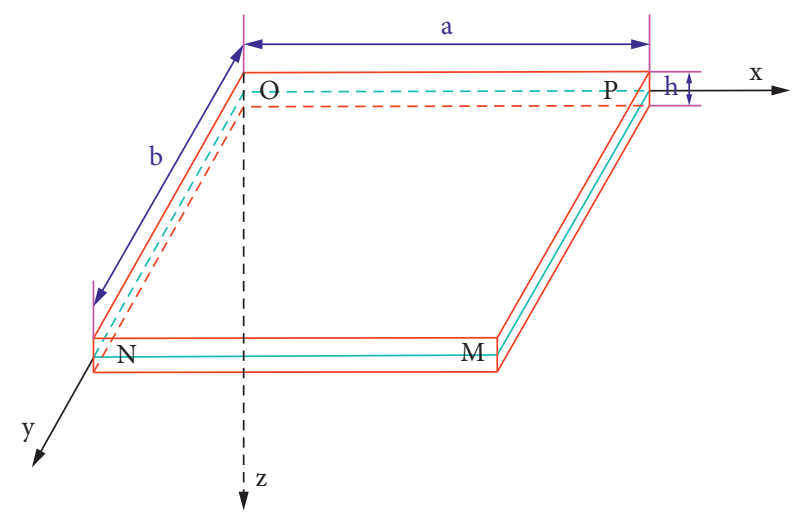

Figure 2: Mechanics model of the unsupported roof.

Suppose the thin plate deflects in the form of a triangle series, namely:

$$
\omega=\sum_{m=1}^{\infty} \sum_{n=1}^{\infty} A_{m n} \sin \frac{m \pi x}{a} \sin \frac{n \pi y}{b} .
$$

The boundary conditions are as follows:

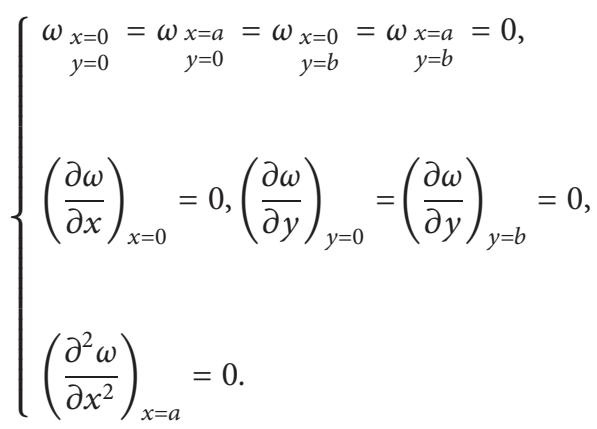

Substituting equation (2) into (3), the deflection of the thin plate satisfies the boundary conditions. According to the thin plate deflection series, the load $q$ is expanded as follows:

$$
q(x, y)=\sum_{m=1}^{\infty} \sum_{n=1}^{\infty} C_{m n} \sin \frac{m \pi x}{a} \sin \frac{n \pi y}{b} .
$$

Based on the orthogonality of the trigonometric series, 


$$
C_{m n}=\frac{4}{a b} \int_{0}^{a} \int_{0}^{b} q(x, y) \sin \frac{m \pi x}{a} \sin \frac{n \pi y}{b} \mathrm{~d} x \mathrm{~d} y .
$$

According to the thin plate balance differential equation, $D \Delta^{4} \omega=q$, and the relationship between $A_{m n}$ and $C_{m n}$ is as follows:

$$
\begin{aligned}
A_{m n} & =\frac{C_{m n}}{D f_{m n}}, \\
f_{m n} & =\pi^{4}\left(\frac{m^{2}}{a^{2}}+\frac{n^{2}}{b^{2}}\right) .
\end{aligned}
$$

When $q(x, y)=q$, if $m$ and $n$ are odd numbers, then $C_{m n}=\left(16 q / \pi^{2} m n\right)$.

If $m$ and $n$ are even numbers, then $C_{m n}=0$.

Therefore, the deflection of the thin plate is as follows:

$$
\omega=\frac{16 q}{\pi^{2} D} \sum_{m=1,3, \ldots}^{\infty} \sum_{n=1,3, \ldots}^{\infty} \frac{1}{m n f_{m n}} \sin \frac{m \pi x}{a} \sin \frac{n \pi y}{b} .
$$

In the actual situation, the unsupported roof is a hinged plate with the greatest force exerted on the two long boundaries. Suppose the neutral plane of the roof is the zerocoordinate plane, then the bottom surface is $z=-(h / 2)$. According to equation (3), tensile stress of the roof is as follows:

$$
\sigma_{x}=\frac{4 \pi^{2} A E h}{a^{2}\left(1-\mu^{2}\right)} \sin ^{2} \frac{\pi y}{b} .
$$

The maximum tensile stress of the unsupported roof is as follows:

$$
\sigma_{x \max }=\frac{4 \pi^{2} A E h}{a^{2}\left(1-\mu^{2}\right)} .
$$

The deflection of the thin plate is the largest in the center, namely, $x=(a / 2)$ and $y=(b / 2)$. According to equation (7), the maximum deflection of the unsupported roof is as follows:

$$
\omega_{\max }=\frac{16 q}{\pi^{2} D} \sum_{m=1,3, \ldots}^{\infty} \sum_{n=1,3, \ldots}^{\infty} \frac{(-1)^{(m+n-2) / 2}}{m n f_{m n}} .
$$

Since the trigonometric series converge quickly, only the first three items are considered in the actual calculation.

Suppose the ultimate tensile strength of the unsupported roof is $\left[\sigma_{t}\right]$, the roof collapses when $\sigma_{x \max }=\left[\sigma_{t}\right][23-26]$. The above parameters are substituted into the above equation to finally determine the maximum unsupported roof length of the roadway.

$$
b=\frac{a}{\sqrt{\sqrt{\left(4 q / \sigma_{t} h^{2}\right)-(8 / 9)}-(1 / 3)}} .
$$

However, in practice, the roof stability of the roof area is influenced by the factors such as the deformation of the coal wall, the decline of the stability of the coal wall, and the decline of the supporting force of the roof area $[27,28]$. At the same time, it will also be affected by the structural characteristics of the roof itself, such as the lithology of the roof and the degree of fragmentation. Therefore, in the calculation of the maximum empty roof distance, a roof edge factor of safety is introduced, which is defined as follows:

$$
\lambda=\frac{\sigma_{t}-\sigma_{x \max }}{\sigma_{t}} .
$$

If $\lambda<0$, the tensile stress exceeds the maximum tensile strength and the unsupported roof collapses; if $\lambda>0$, the tensile stress is within the tensile strength limit and the unsupported roof does not collapse. Here, the unsupported roof length when $\lambda=0$ is the critical unsupported roof length when the roof starts to collapse. The relationship between the unsupported roof length and the surplus safety factor during roadway excavation is as follows:

$$
b_{m}=\frac{a}{\sqrt{\sqrt{\left(4 q /(1-\lambda) \sigma_{t} h^{2}\right)-(8 / 9)}-(1 / 3)}} .
$$

\section{Stress Evolution Characteristics and Stability Factors of the Unsupported Roof}

3.1. Modeling. Roadway 150802 with a rectangular cross section of $5.8 \times 4.2 \mathrm{~m}$ was taken as the research object. A FLAC 3D numerical model was built according to the engineering geological conditions of the roadway. The dimension of model was $60 \mathrm{~m} \times 50 \mathrm{~m} \times 40 \mathrm{~m}$. With a fixed bottom and displacement boundaries of four vertical sides, overburden load of the model was applied on the top surface. Taking into account the speed and accuracy of the calculation, the roof and floor grids in the vicinity of the roadway were densified into a total of 140,124 units. The grids of the rock strata near the coal seam were densified into cubes of $0.5 \times 0.5 \mathrm{~m}$, and the grid size of the rock strata in other roof and floor areas remained larger as $1.0 \times 1.0 \mathrm{~m}$ cubes. Figure 3 shows the numerical calculation model.

In the calculation, mechanical parameters of coal and rock mass were from related geological reports and laboratory tests. Table 1 shows the specific mechanical parameters of the coal roof and floor.

During roadway excavation, collapse of the surrounding rock mass is mainly due to tensile-shear force, so the Mohr-Coulomb yield criterion is introduced to the calculation of the numerical model.

3.2. Simulation Design and Result Analysis. According to equation (9), factors affecting the stability of the unsupported roof are depth $(500,550,600$, and $650 \mathrm{~m})$, roof thickness $(1,2,3$, and $4 \mathrm{~m})$, and unsupported roof length (1, 2,3 , and $4 \mathrm{~m}$ ). To determine the influence of each factor on the stability of the unsupported roof, a scheme is designed as shown in Table 2.

3.3. Characteristics of Roof Stress Evolution. By simulating the changes in each factor listed in Table 1, the resulted vertical stress of the roadway roof is calculated and recorded 


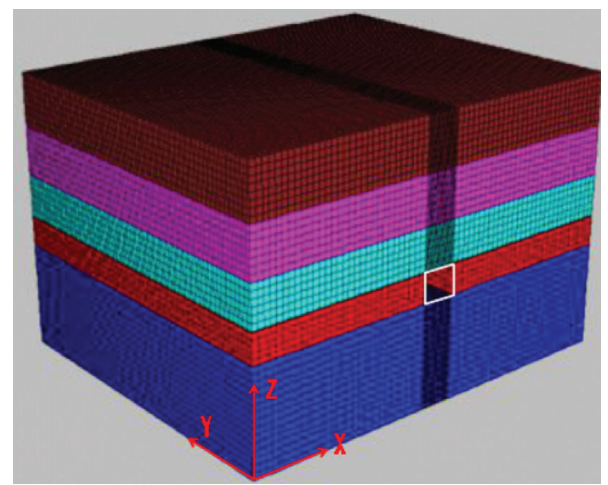

FIGURE 3: Numerical calculation model.

TABle 1: Mechanical parameters of the coal roof and floor.

\begin{tabular}{|c|c|c|c|c|c|c|c|}
\hline No. & Lithology & Thickness (m) & Density $\left(\mathrm{kg} / \mathrm{m}^{3}\right)$ & Bulk modulus (GPa) & $\begin{array}{c}\text { Shear } \\
\text { modulus }(\mathrm{GPa})\end{array}$ & $\begin{array}{c}\text { Internal friction } \\
\text { angle }\left({ }^{\circ}\right)\end{array}$ & Cohesion (MPa) \\
\hline 5 & Fine sandstone & 7.74 & 2700 & 8.35 & 7.1 & 35 & 3.75 \\
\hline 4 & Sandy mudstone & 1.15 & 2500 & 5.2 & 3.4 & 30 & 2.05 \\
\hline 3 & 8 coal & 3.54 & 1400 & 1.5 & 0.63 & 23 & 0.72 \\
\hline 2 & Mudstone & 3.01 & 2400 & 3.58 & 1.53 & 23 & 1.17 \\
\hline 1 & Siltstone & 4.35 & 2500 & 6.5 & 6.74 & 32 & 3.15 \\
\hline
\end{tabular}

TABLE 2: Simulation scheme.

\begin{tabular}{lccc}
\hline Program & Depth $(\mathrm{m})$ & $\begin{array}{c}\text { Unsupported } \\
\text { roof length }(\mathrm{m})\end{array}$ & $\begin{array}{c}\text { Thickness of soft } \\
\text { rock roof }(\mathrm{m})\end{array}$ \\
\hline a-1 & 500 & 1.0 & 2.0 \\
a-2 & 550 & 1.0 & 2.0 \\
a-3 & 600 & 1.0 & 2.0 \\
a-4 & 650 & 1.0 & 2.0 \\
b-1 & 550 & 1.0 & 2.0 \\
b-2 & 550 & 2.0 & 2.0 \\
b-3 & 550 & 3.0 & 2.0 \\
b-4 & 550 & 4.0 & 2.0 \\
c-1 & 550 & 1.0 & 1.0 \\
c-2 & 550 & 1.0 & 2.0 \\
c-3 & 550 & 1.0 & 3.0 \\
c-4 & 550 & 1.0 & 4.0 \\
\hline
\end{tabular}

in Figures 4 to 6 . It can be seen from Figures 4 to 6 that the order of the impact on the vertical stress of the coal roof is load $>$ roof thickness $>$ empty roof distance. The vertical stress of the coal roof is directly proportional to the load of the overburden. As the load of the overburden increases, the vertical stress of the coal roof continues to increase; it is different from the thickness of the roof in the range of the roadway and solid coal. That is to say, increasing the thickness of the roof and the roadway, the vertical stress of the roof increases, while the vertical stress of the roof in front of the coal wall of the two sides and the tunneling face decreases, and the decreasing trend gradually slows down; increasing the empty roof distance has basically no effect on the vertical stress of the coal roof.

3.4. Factors of Roof Stability. To determine the influence of each factor on the stability of the unsupported roof during roadway excavation, tensile stress of the unsupported roof

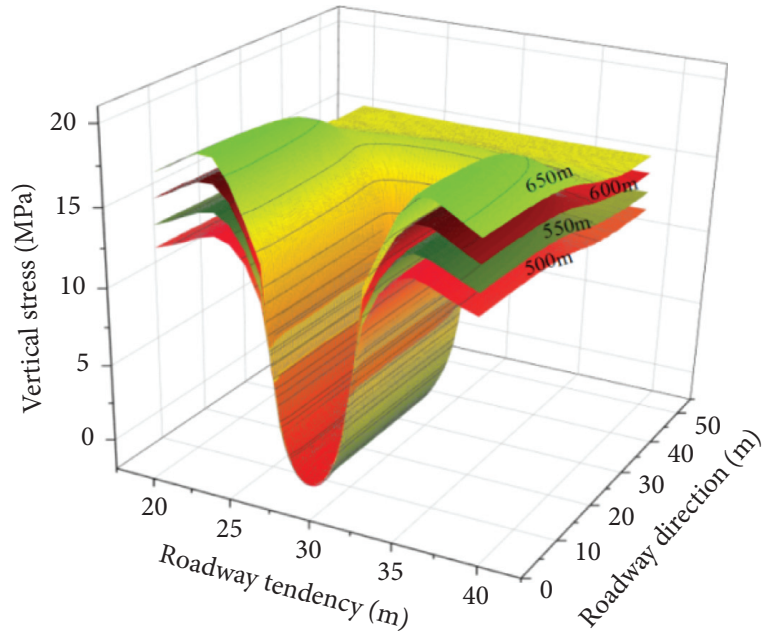

Figure 4: Vertical stress evolution of the roof at different depths.

was measured as shown in Figures 7 to 9. According to Figures 7 to 9,

(1) The curve correlation coefficients of tensile stress in the unsupported roof and the three factors from the largest to the smallest are $R_{c}>R_{b}>R_{a}$; that is, the largest influencing factor of unsupported roof stability is the thickness of the soft rock, followed by the length of the unsupported roof and the depth of the roadway.

(2) The tensile stress in the unsupported roof increases linearly with the increase in the roadway depth; the tensile stress in the unsupported roof increases exponentially with the length of the unsupported roof; the tensile stress in the unsupported roof decreases exponentially with the thickness of the soft rock. 


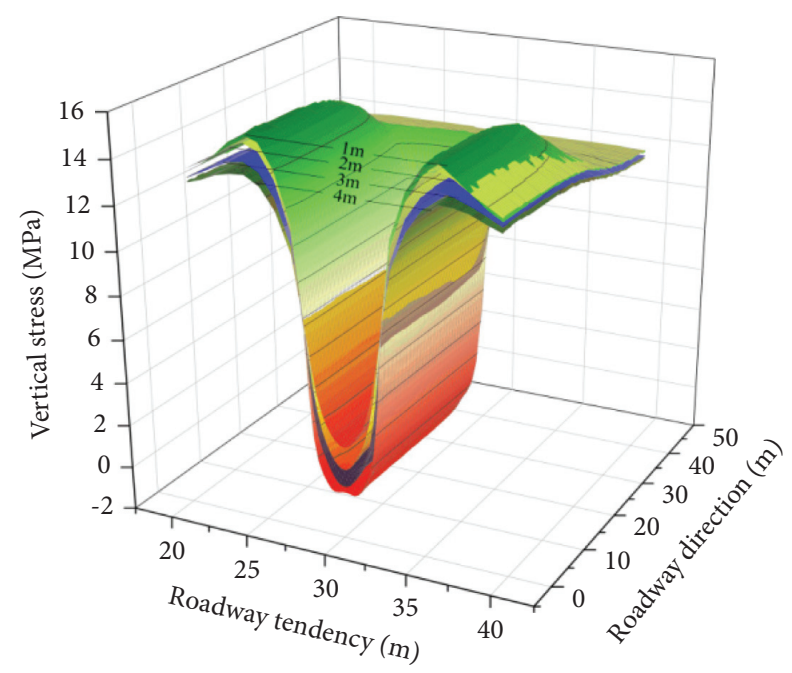

Figure 5: Vertical stress evolution of different roof thicknesses.

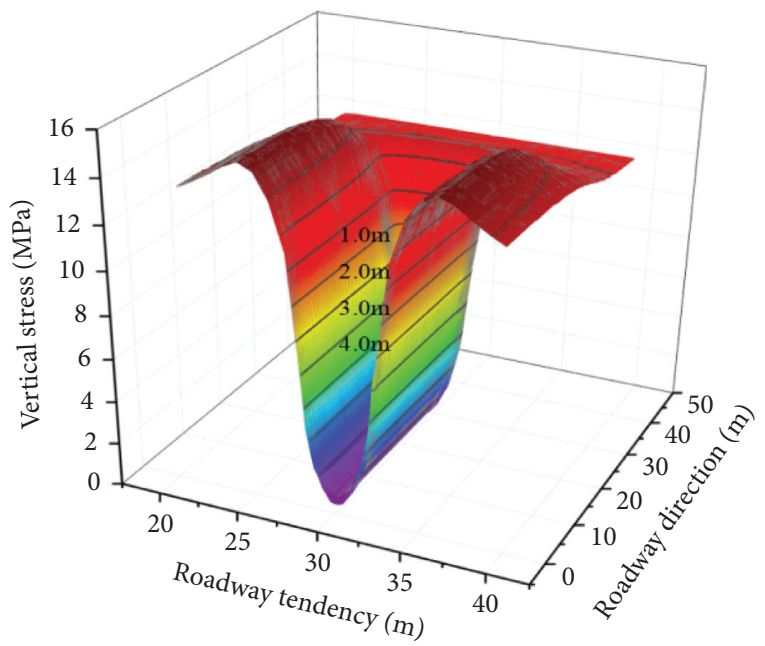

FIGURE 6: Vertical stress evolution at different unsupported roof lengths.

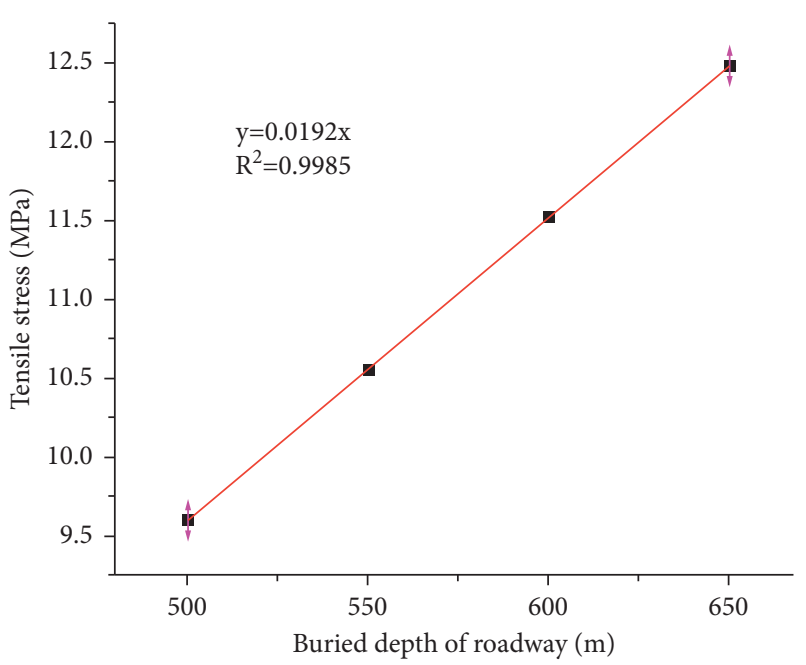

Figure 7: The relationship between the tensile stress in the unsupported roof and roadway depth.

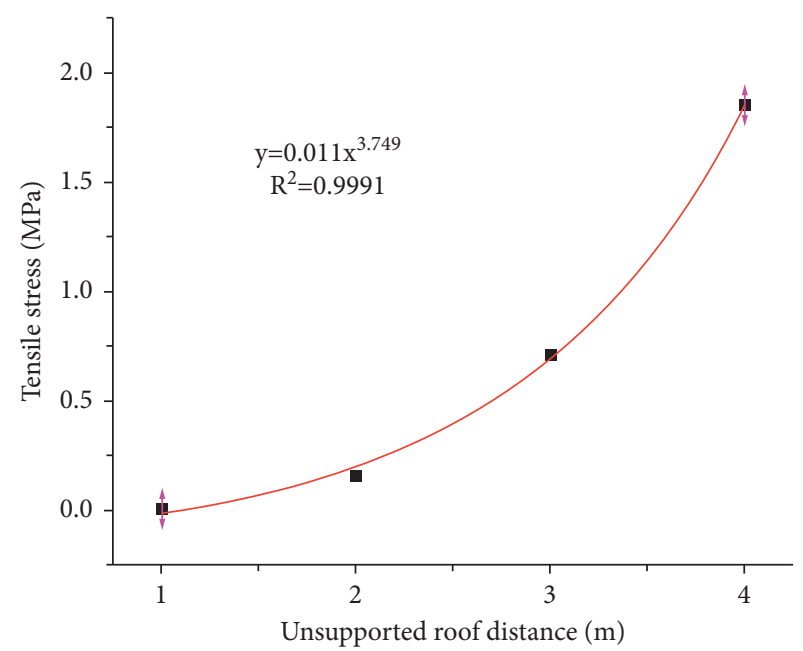

Figure 8: The relationship between the tensile stress in the unsupported roof and unsupported roof distance.

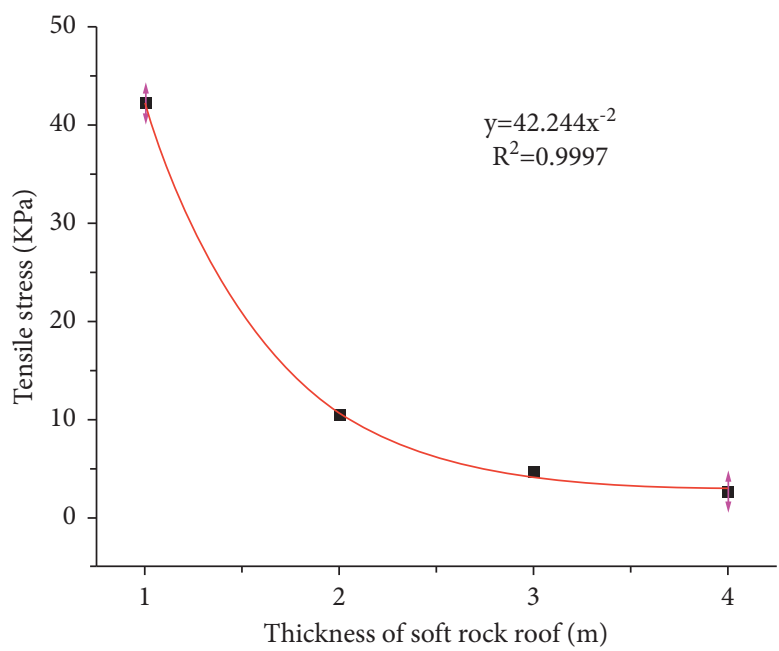

Figure 9: The relationship between the tensile stress in the unsupported roof and soft rock thickness.

In practice, changes in the depth of the roadway are often negligible while the structure and thickness of the surrounding rock strata change constantly. Therefore, two of the key factors, the thickness of the soft rock and the length of the unsupported roof, are selected for further analysis. The changes of tensile stress in the unsupported roof with the increase in soft rock thickness and unsupported roof length are shown in Figure 10. According to Figure 10, the tensile stress in the unsupported roof is relatively small as long as the thickness of the soft rock exceeds $0.5 \mathrm{~m}$ or the length of the unsupported roof does not exceed $3.0 \mathrm{~m}$; otherwise, the tensile stress in the unsupported roof increases rapidly, causing decrease in the stability of the roof.

3.5. Example Calculation. In order to determine the physical and mechanical parameters of coal seam roof rock mass, by collecting the geological data of 150802 well, it is found that 


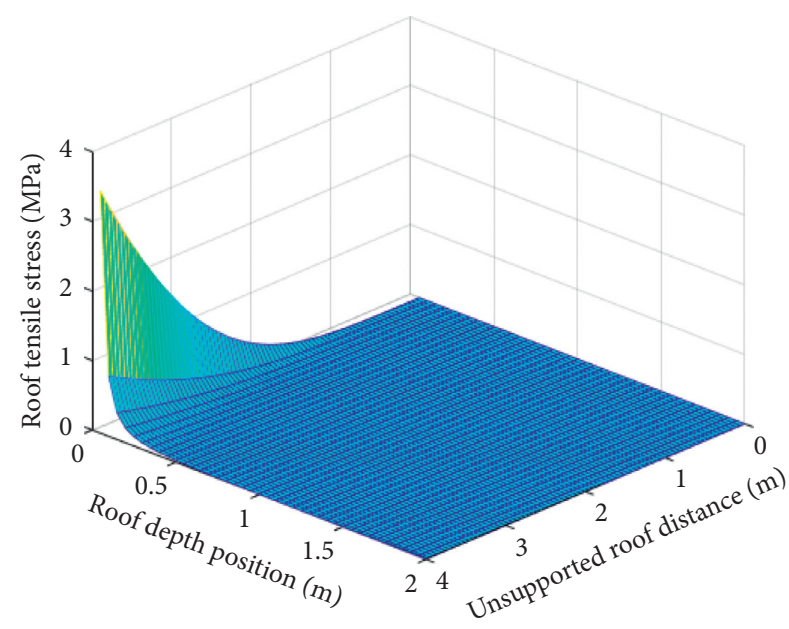

Figure 10: Tensile stress distribution of the unsupported roof.

the direct roof of 150802 well is soft mudstone, and the roof rock is drilled and cored. Uniaxial compression and uniaxial tensile tests were carried out indoors using the test equipment shown in Figure 11. Figure 12 shows the drilling and coring work and laboratory test of 150802 machine roadway on-site.

Depth of roadway 150802 is about $570 \mathrm{~m}$, thickness of the direct roof mudstone is $1.15 \mathrm{~m}$, roadway width is $5.8 \mathrm{~m}$, tensile strength is $2.03 \mathrm{MPa}$, elastic modulus $E$ is $315 \mathrm{MPa}$, Poisson's ratio $\mu$ is 0.36 , average volume force is $25 \mathrm{kN} / \mathrm{m}^{3}$, and $q=25 \times 570 \mathrm{kPa}=14.25 \mathrm{MPa}$. According to equation (11), the maximum unsupported roof length $b=2.72 \mathrm{~m}$. The curve of tensile stress in the unsupported roof, as shown in Figure 13, is drawn based on equation (9). According to Figure 11, tensile stress in the unsupported roof increases exponentially with the increase in the unsupported roof length, while the surplus safety factor decreases logarithmically. Tensile stress exceeds maximum tensile strength of the unsupported roof when the unsupported roof length reaches $2.72 \mathrm{~m}$, resulting in collapse of the roof.

To ensure the stability of the unsupported roof during roadway excavation, a reasonable surplus safety factor is introduced. According to equation (13), the relationship between the surplus safety factor and the maximum unsupported roof length is plotted as shown in Figure 14. According to Figure 14, maximum unsupported roof length decreases with the increase in the surplus safety factor. To ensure the stability of the unsupported roof, the surplus safety factor should be above 0.6 [29]. The unsupported roof is stable with unsupported roof length under $2.08 \mathrm{~m}$, moderately stabile with unsupported roof length ranging from 2.08 to $2.72 \mathrm{~m}$, or unstable with unsupported roof length over $2.72 \mathrm{~m}$. Therefore, the unsupported roof length during roadway excavation should not exceed $2.08 \mathrm{~m}$.

To analyze the change of maximum deflection with the increase in unsupported roof length, the roof deflection curve, as shown in Figure 15, is plotted based on equation (10). According to Figure 15, deflection of the unsupported

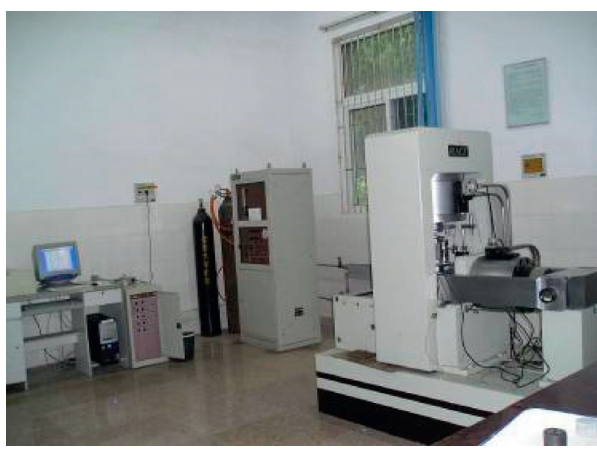

FIGURE 11: RMT rock mechanics test system.

roof increases exponentially with the increase in unsupported roof length. Figure 16 shows the deflection of the entire roof when the unsupported roof length is $2.08 \mathrm{~m}$ with the maximum subsidence of $43.17 \mathrm{~mm}$.

3.6. Field Testing. As shown in Figure 17, roadway 150802 is adjacent to mining area 1508 on the east, connected to working face 150802 in the west and north and working face 150804 in the south. Above roadway 150802 is the goaf area of working face 151101 and 151102 . The distribution of coal seams and roof and floor strata of 150802 roadway is shown in Table 3.

As shown in Figure 18, the roadway roof is reinforced with bolt-net-cable support. The bolts are left-handed threaded strong metal bolts with a diameter of $22 \mathrm{~mm}$ and a length of $2.5 \mathrm{~m}$. Each bolt is $800 \mathrm{~mm}$ apart from the adjacent bolt and solidified with one CK2340 and two K2340 resin anchoring cartridges. For roll anchoring, the pretightening force of the anchor rod is not less than $50 \mathrm{kN}$. The anchor cable is made of prestressed steel strand with a diameter of $21.8 \mathrm{~mm}$ and a length of $7.2 \mathrm{~m}$. Each anchor cable is $1,200 \mathrm{~mm}$ apart from the adjacent cable and solidified with one roll of MSK2850 and two rolls of MSZ2850 resin anchoring cartridges.

Roadway 150802 is excavated with a type EBZ220M double anchor roadheader, a belt conveyer, and a DWZY1000-1200 (A) step-type self-moving tail as shown in Figure 19. Among them, the EBZ220M double-anchor roadheader is responsible for roadway excavation, discharging, installing anchor rod, and anchor cable support; the belt conveyer transfers the discharge onto the step-type self-moving machine; the DWZY1000/1200 (A) step-type self-moving tail serves as the extension of the belt conveyer. In the process of roadway excavation, it is excavated along the $8 \#$ coal seam roof.

Although theoretical calculations placed the unsupported roof length during roadway 150802 excavation under $2.08 \mathrm{~m}$, on-site construction conditions further limited it to $2.0 \mathrm{~m}$ without significant influence on the field test results. As shown in Figure 20, after excavating one unsupported roof length, temporary roof support is deployed along with hanging nets. If the temporary support is firm and reliable, on-board hydraulics are deployed and roof bolters (cables) are installed. The equipment of the rapid tunneling system is 


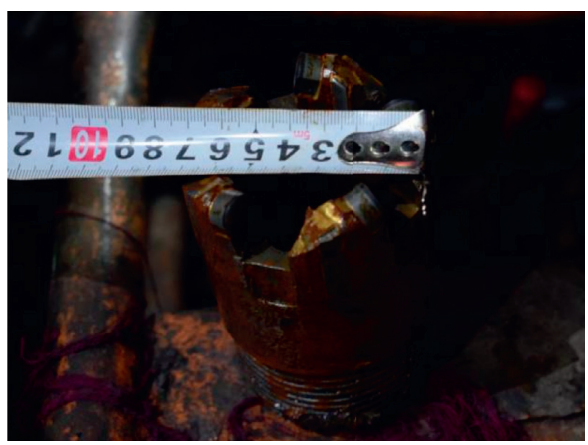

(a)

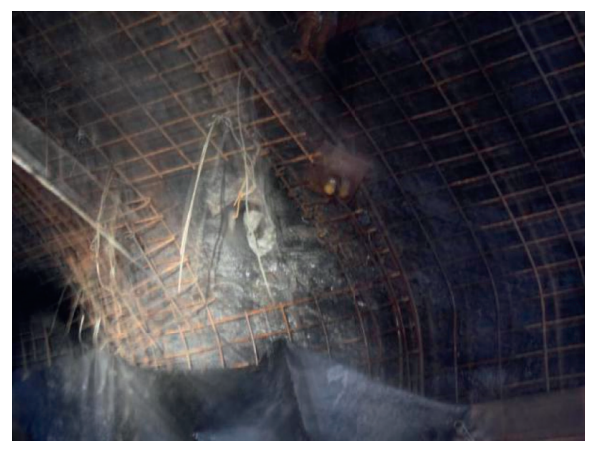

(b)

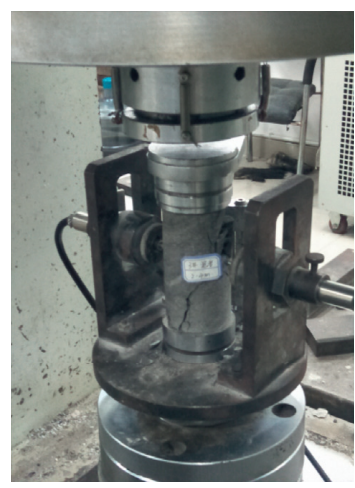

(c)

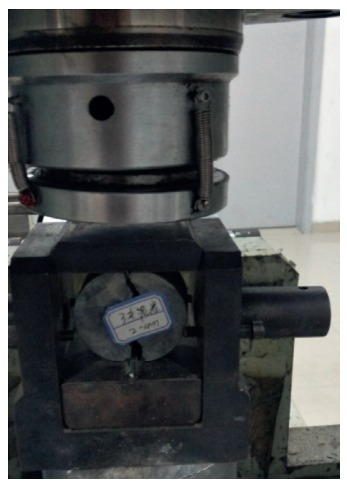

(d)

Figure 12: Field coring and laboratory test. (a) Coring bit. (b) Roof drilling. (c) Uniaxial compression. (d) Uniaxial tension.

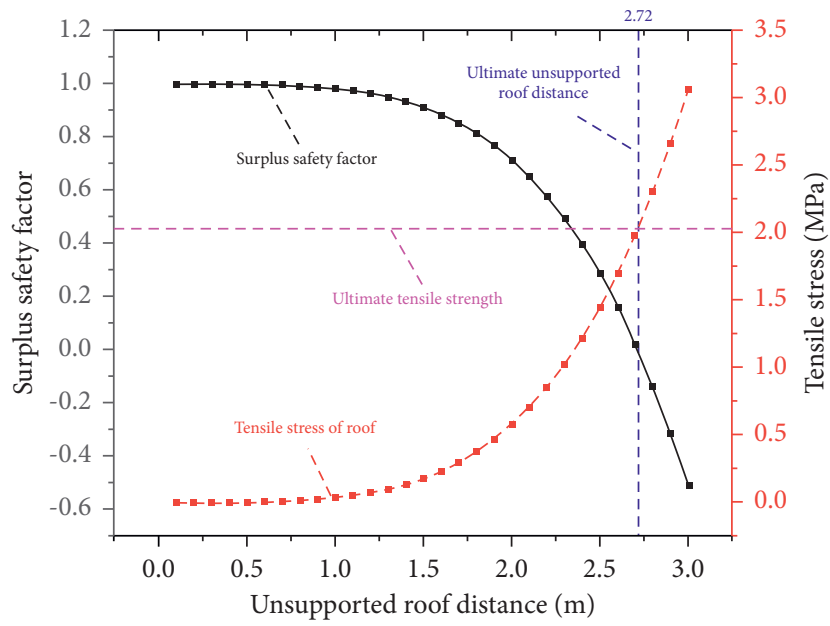

FIgURE 13: Curve of the tensile stress in the unsupported roof.

compared with the traditional comprehensive tunneling equipment, as shown in Table 4.

The "cross point method" is used to analyze the deformation of $2.0 \mathrm{~m}$ roadway without supporting roof. The measuring station is arranged at 500 away from the starting point of the roadway, and it is monitored every 24 hours, and the observation results are shown in Figure 21. According to the deformation curve of roadway, the relative displacement of roof and floor is $59 \mathrm{~mm}$ and that of both sides is $84 \mathrm{~mm}$. Therefore, the direct roof and both sides of the roadway are relatively stable.

As shown in Figure 22, after setting the unsupported roof length to $2.0 \mathrm{~m}$, tunneling speed increased $62.7 \%$, of which the extended unsupported roof length accounted for $30.8 \%$ and the rapid tunneling system equipment accounted for $31.9 \%$, achieving a monthly progress over $500 \mathrm{~m}$. 


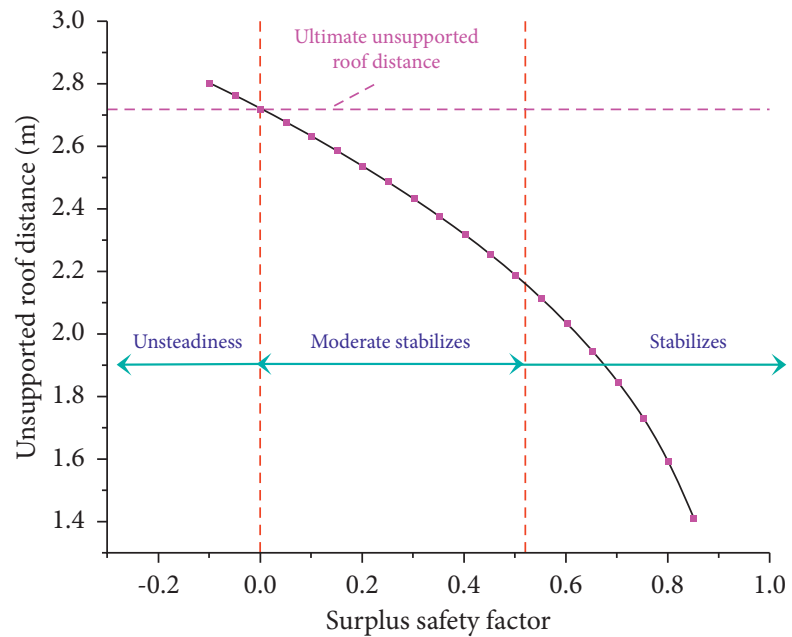

FIGURE 14: The relationship between the surplus safety factor and the maximum unsupported roof length.

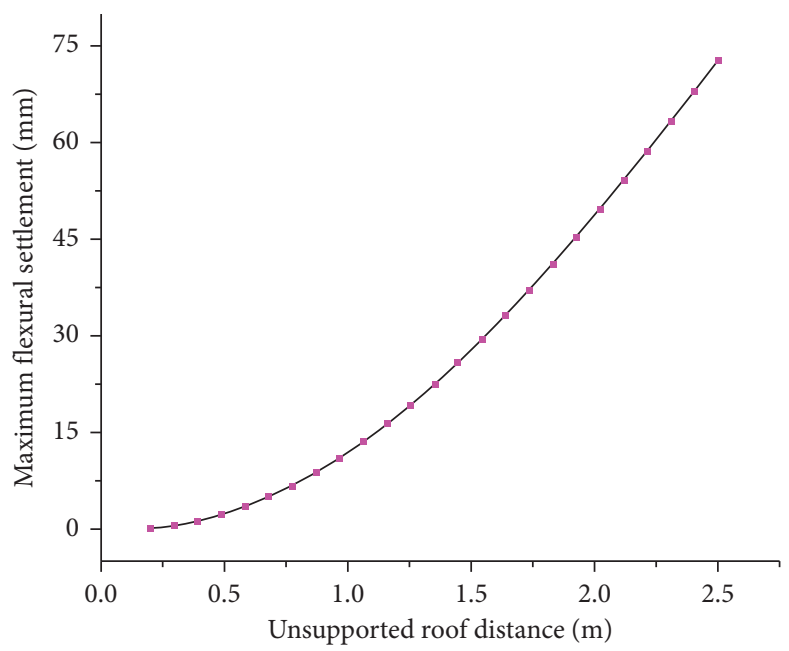

FIgURE 15: The relationship between the maximum deflection and the length of the unsupported roof.

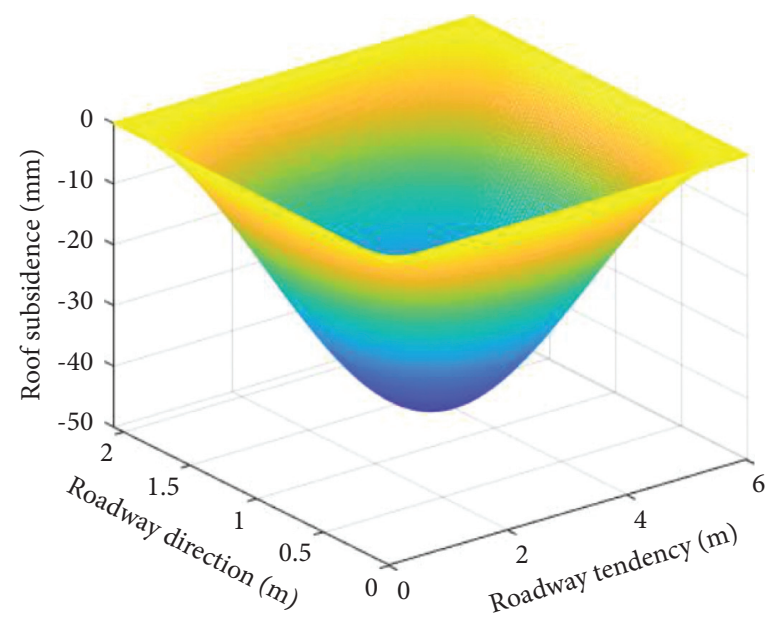

Figure 16: Subsidence of the unsupported roof. 


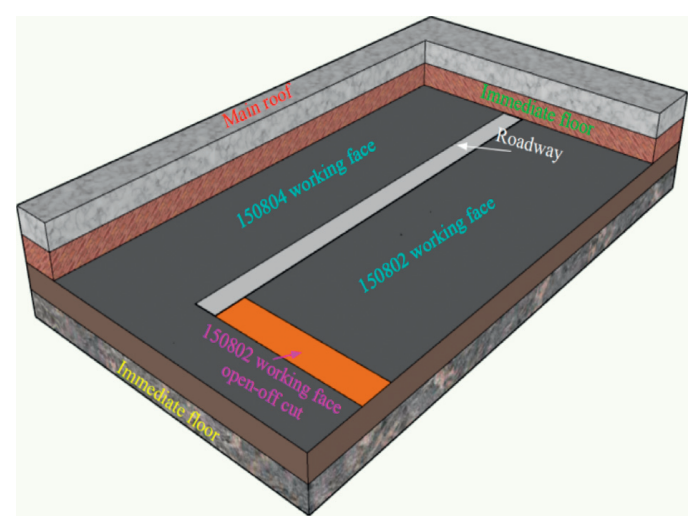

FIgURE 17: Layout of roadway 150802.

TABLe 3: Distribution of $8^{\#}$ coal and roof and floor strata.

\begin{tabular}{|c|c|c|c|}
\hline No. & Lithology & $\begin{array}{l}\text { Thickness } \\
(\mathrm{m})\end{array}$ & Lithology description \\
\hline 5 & $\begin{array}{c}\text { Fine } \\
\text { sandstone }\end{array}$ & 7.74 & $\begin{array}{c}\text { Gray, grayish white, mainly composed of quartz, containing dark minerals and muscovite fragments } \\
\text { and argillaceous siliceous cementation }\end{array}$ \\
\hline 4 & $\begin{array}{l}\text { Sandy } \\
\text { mudstone }\end{array}$ & 1.15 & Gray, dense, brittle, flat section, containing more phytochemical fragments \\
\hline 3 & 8 coal & 3.54 & $\begin{array}{c}\text { It is mainly powdery, belonging to semidark and semibright briquette, and some contain coal gangue } \\
\text { and carbonaceous shale }\end{array}$ \\
\hline 2 & Mudstone & 3.01 & Gray-dark gray, dense, brittle, rich in rooted fossils \\
\hline 1 & Siltstone & 4.35 & $\begin{array}{c}\text { Gray-light gray, dense, brittle, containing plant fossils and vein bedding, with siderite sandstone at the } \\
\text { bottom }\end{array}$ \\
\hline
\end{tabular}

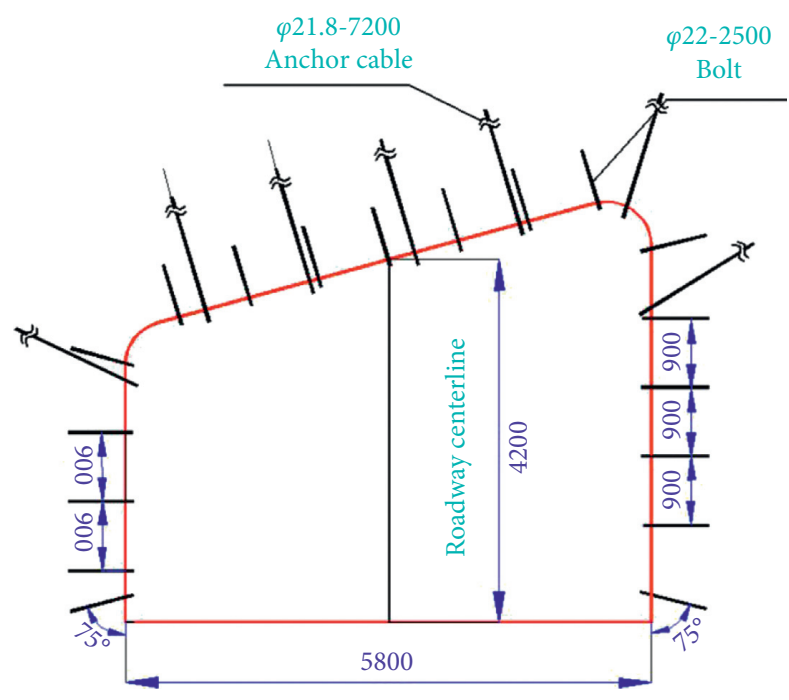

FIGURE 18: Roadway support section. 


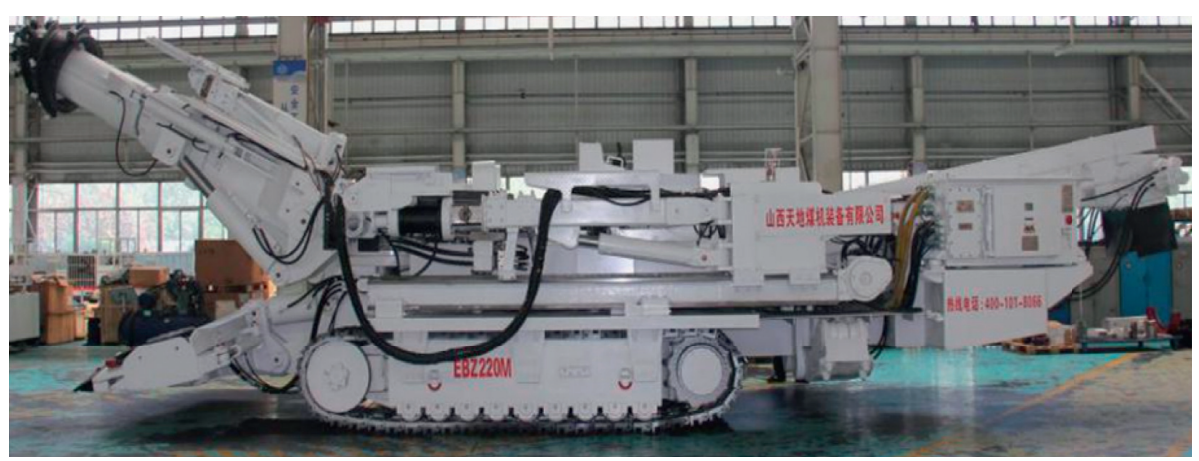

Type EBZ220M double anchor roadheader

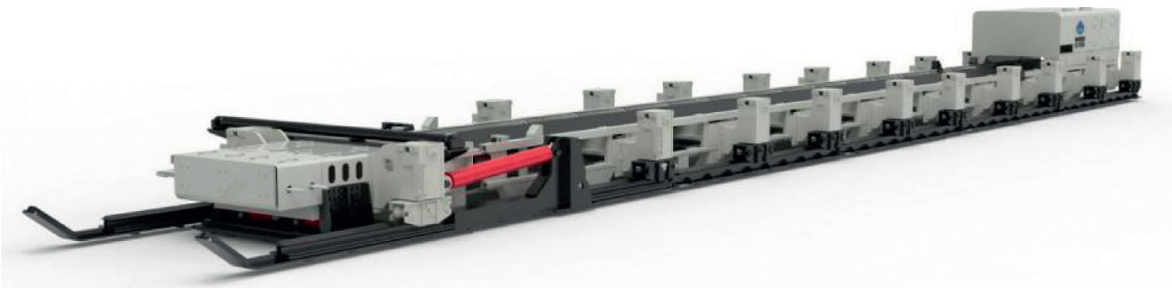

DWZY1000/1200 step-type self-moving machine tail

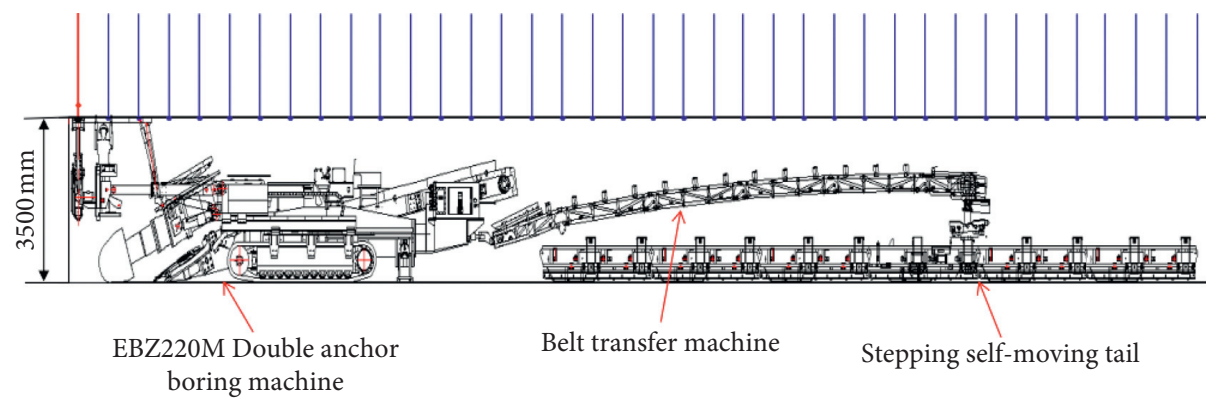

FIgURE 19: Equipment for the rapid excavation system.

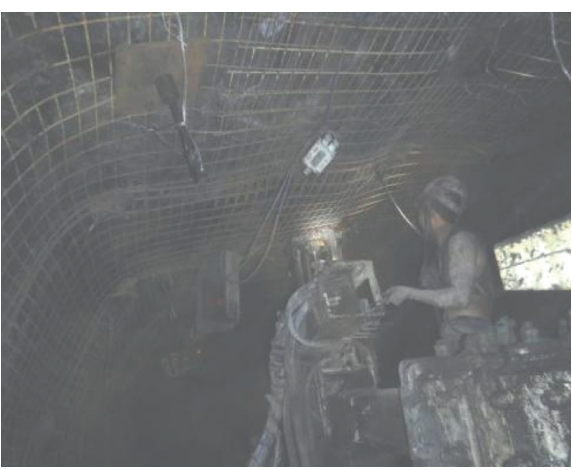

(a)

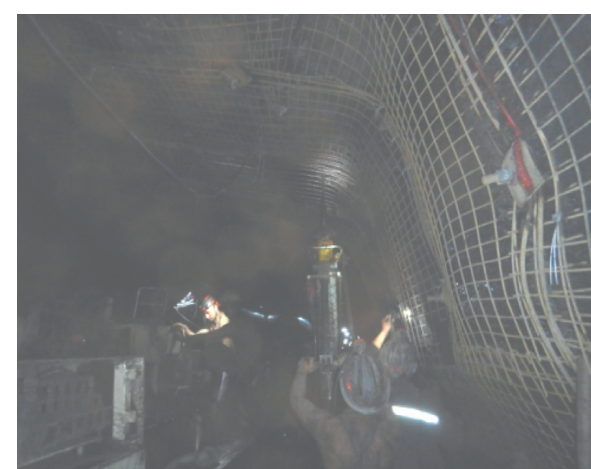

(b)

FIGURE 20: On-site installation of bolt support. (a) Hydraulic bolting rig in action. (b) Hand-held pneumatic bolt drill in action.

TABle 4: Comparison of equipment of rapid excavation system and traditional comprehensive excavation equipment.

\begin{tabular}{lll}
\hline Effect comparison & \multicolumn{1}{c}{ Rapid tunneling system technology } & \multicolumn{1}{c}{ Traditional tunneling technology } \\
\hline & $\begin{array}{l}\text { (1) The left and right drilling rigs need } 1 \text { person to } \\
\text { operate each and } 1 \text { person to assist ( } 3 \text { persons). }\end{array}$ & $\begin{array}{l}\text { (1) The are two cable anchors head-on, each of } \\
\text { which requires two people to operate and one } \\
\text { person to assist (5 people). }\end{array}$ \\
Reduce the number of support & (2) 2 typhoon coal drills make up the assistance, & (2) 2 typhoon coal drills make up the assistance, \\
operations in the unsupported & $\begin{array}{l}\text { each requires } 2 \text { persons ( } 4 \text { persons). } \\
\text { roof area }\end{array}$ \\
(3) The number of people supported by the airborne & \\
bolter is 7 people. The support staff is reduced by & (3) The number of anchor anchors is 9 people. \\
20\% per shift. &
\end{tabular}


TABle 4: Continued.

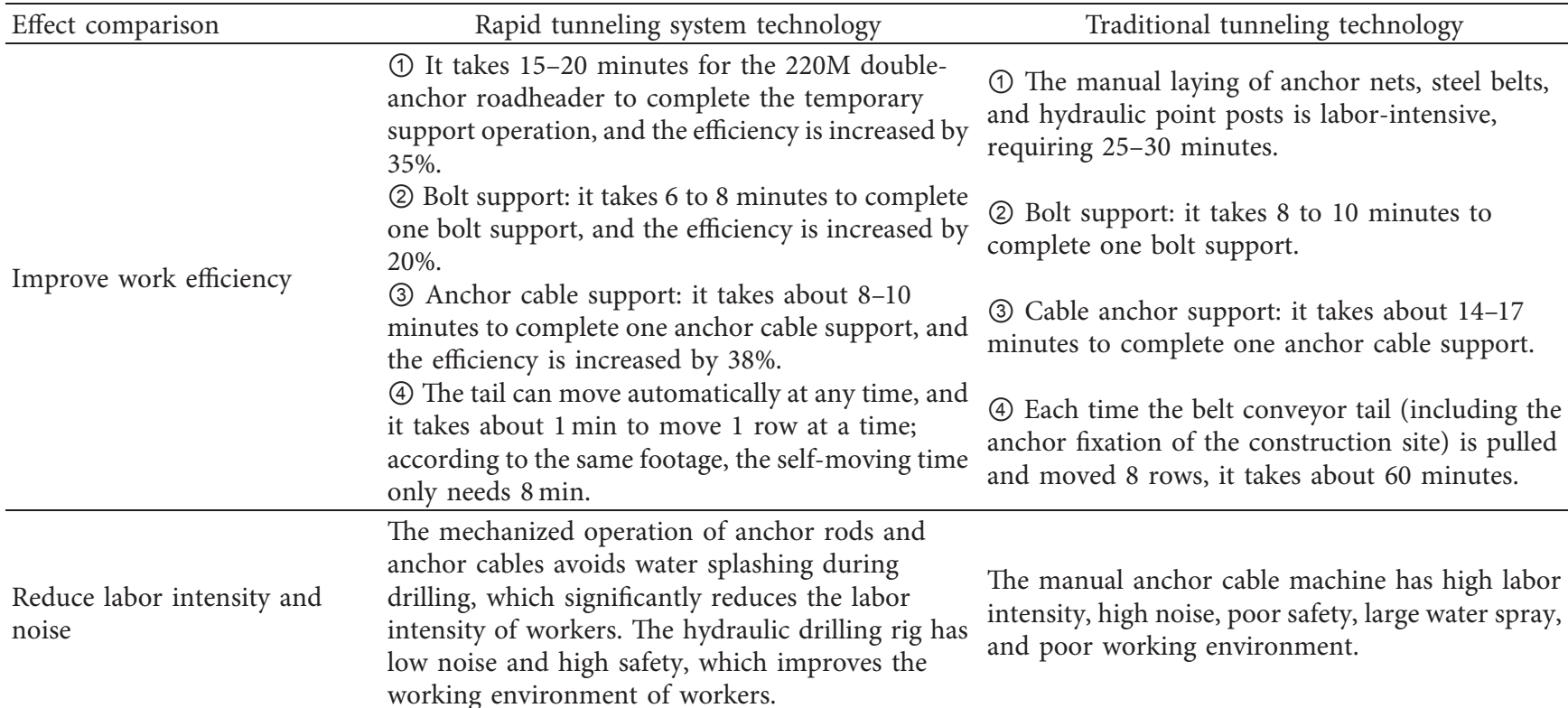
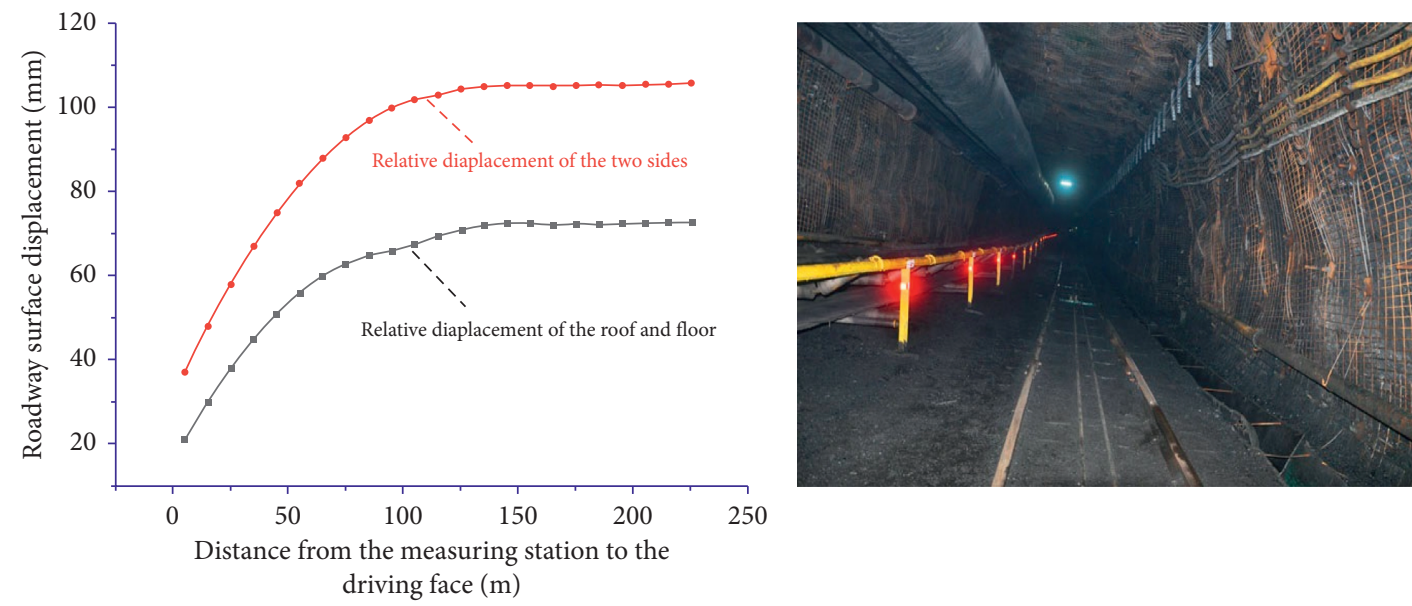

Figure 21: Roadway deformation.

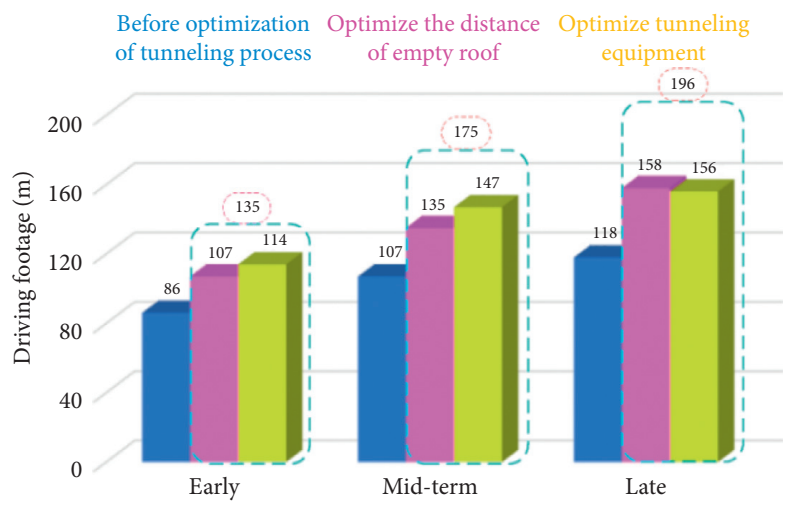

FIgURE 22: Comparison of application effects. 


\section{Conclusion}

(1) With the thin plate mechanical model of the unsupported roof, the equation for the tensile stress and deflection of the unsupported is deduced. According to the relationship between the tensile stress and tensile strength of the unsupported roof, a primary unsupported roof length is set. Considering on-site situation of roadway excavation, a surplus safety factor is introduced.

(2) According to the equation for the tensile stress in the unsupported roof, stability factors, namely, the length of the unsupported roof, the thickness of the roof, and the depth of the roadway, are determined. Considering the geological conditions of roadway 150802, FLAC 3D numerical simulation software is used to simulate the influence of each factor on the stability of the unsupported roof. The extent of influence each factor has on the tensile stress in the unsupported roof was analyzed by regression analysis of the relationship between the factors and the tensile stress. The unsupported roof stability factors ranking from largest to smallest are roof thickness, unsupported roof length, and roadway depth.

(3) According to the theoretical and numerical simulation and on-site construction conditions of roadway 150802 , the reasonable unsupported roof length during excavation is set to $2.0 \mathrm{~m}$ and tested with a complete set of rapid excavation system equipment. Compared with precious roadway, comprehensive excavation speed increased $62.7 \%$ with the extended unsupported roof length accounting for $30.8 \%$ and the complete set of rapid excavation system equipment accounting for $31.9 \%$, achieving a monthly progress over $500 \mathrm{~m}$.

\section{Data Availability}

The data used in the field measurement are obtained from the corresponding author upon request.

\section{Conflicts of Interest}

The authors declare that there are no conflicts of interest with respect to the research, authorship, and/or publication of this article.

\section{Authors' Contributions}

During the research, Xiao Liu and Chen Li reviewed and modified the manuscript. All authors contributed to this article.

\section{Acknowledgments}

The authors would like to thank Professor Hua Xinzhu for his guidance in this paper. The authors acknowledge the financial support for this work provided by the National Natural Science Foundation of China (grant no. 51774010).

\section{References}

[1] K. Z. Zhang and H. W. Liu, "Measurement analysis of influencing factors of rock tunnel excavation speed in Qianyingzi coal mine," Energy Technology and Management, vol. 38, no. 4, pp. 91-93, 2013.

[2] C. L. Ma, L. F. Yuan, and Y. Zhang, "Construction technology of rapid excavation of large section coal roadway," Coal Mine Safety, vol. 44, no. 5, pp. 98-100, 2013.

[3] C. Hu, "Reasonable empty and roof spacing design of continuous miner heading face in boundary lane of No. 52 coal mine in Yujialiang coal mine," Coal, vol. 25, no. 6, pp. 18-19, 2016.

[4] P. Ma, D. Qian, N. Zhang, H. Shimada, D. Pan, and K. Huang, "Application of bolter miner rapid excavation technology in deep underground roadway in inner Mongolia: a case study," Sustainability, vol. 12, pp. 1-17, 2020.

[5] W. F. Yan and L. Shi, "The development status of coal roadway excavation technology and equipment in China," Coal Mine Machinery, vol. 39, no. 12, pp. 1-3, 2018.

[6] J. H. Wang, "China mechanized road header status and bolt support technology in mine seam roadway," Coal Science and Technology, vol. 31, no. 1, pp. 6-10, 2014.

[7] G. F. Wang, H. Wang, and H. W. Ren, "Smart coal mine 2025 scenario goal and development path," Journal of China Coal Society, vol. 43, no. 2, pp. 295-305, 2018.

[8] L. H. Lv, D. H. Yang, and D. Wang, "Numerical optimization of bolt support parameters for rapid roadway excavation," Journal of Shanxi Datong University (Natural Science Edition), vol. 32, no. 2, pp. 61-65+68, 2016.

[9] J. Y. Tian, Research on Optimization of Rectangular Coal Roadway Support under Horizontal Stress Conditions, Kunming University of Science and Technology, Xishan, Kunming, China, 2017.

[10] B. Jca, Z. A. Nong, B. Sw, D. Qian, and Z. Xie, "Physical model test study on support of super pre-stressed anchor in the mining engineering," Engineering Failure Analysis, vol. 118, Article ID 104833, 2020.

[11] B. Tang, H. Cheng, Y. Tang et al., "Supporting design optimization of tunnel boring machines-excavated coal mine roadways: a case study in zhangji, China," Processes, vol. 8, no. 1, p. 46, 2020.

[12] C. Zhang, C. Pu, R. Cao, T. Jiang, and G. Huang, "The stability and roof-support optimization of roadways passing through unfavorable geological bodies using advanced detection and monitoring methods, among others, in the Sanmenxia Bauxite Mine in China's Henan Province," Bulletin of Engineering Geology and the Environment, vol. 78, no. 7, pp. 5087-5099, 2019.

[13] M. J. Fan, "Determination of reasonable empty roof distance for large section coal roadway in deep mine," Coal Technology, vol. 35, no. 11, pp. 60-62, 2016.

[14] R. Ma, The Roof Failure Mechanism and Stability Control of the Roof in the Empty Roof Area of Rapid Roadway Excavation, China University of Mining and Technology, Xuzhou, China, 2016.

[15] P. Q. Wu, "Research on the self-stabilization law of the empty roof and optimization of the construction plan for the rapid excavation of coal roadways," China University of Mining and Technology, vol. 34, no. 12, pp. 1585-1593, 2017.

[16] Z. Q. Zhang, Research on the Spatiotemporal Evolution Characteristics and Support Mechanism of the Stress Crust of the Surrounding Rock of Deep Roadway, China University of Mining and Technology, Beijing, China, 2018. 
[17] M. Cai and P. K. Kaiser, "In-situ rock spalling strength near excavation boundaries," Rock Mechanics and Rock Engineering, vol. 47, no. 2, pp. 659-675, 2014.

[18] S. Wang, X. Li, and S. Wang, "Separation and fracturing in overlying strata disturbed by longwall mining in a mineral deposit seam," Engineering Geology, vol. 226, pp. 257-266, 2017.

[19] S. Q. Niu, S. S. Yang, and Y. Li, "Shearing instability mechanism and support method of roof layer of large-span roadway," Journal of China Coal Society, vol. 39, no. S2, pp. 325-331, 2014.

[20] B. Zya, L. C. Chang, and A. Hz, "Mechanism of rock burst caused by fracture of key strata during irregular working face mining and its prevention methods," International Journal of Mining Science and Technology, vol. 29, no. 6, pp. 889-897, 2019.

[21] J. L. Wu, Elasticity, pp. 317-324, Higher Education Press, Beijing, China, 2001.

[22] Z. Y. Xia, Z. Y. Tan, and J. F. Zhang, "Study on instability mechanism of extraction structure under undercut space based on thin plate theory in block caving method," Shock and Vibration, vol. 2021, Article ID 5548213, 11 pages, 2021.

[23] J. Yao and J. W. Chao, "Numerical simulation research on the stress distribution law of the roof of the roadway crossing faults," Express Information of Mining Industry, vol. 11, pp. 14-16, 2007.

[24] J. He, L. M. Dou, Z. L. Mu, A. Cao, and S. Gong, "Numerical simulation study on hard-thick roof inducing rock burst in coal mine," Journal of Central South University, vol. 23, pp. 2314-2320, 2016.

[25] L. Ma, "Numerical simulation study on the mechanism of roof rock burst under tensile stress," Heilongjiang Science and Technology Information, vol. 30, p. 230, 2014.

[26] X. Liu, X. Hua, P. Yang, and Z. Huang, "A study of the mechanical structure of the direct roof during the whole process of non-pillar gob-side entry retaining by roof cutting," Energy Exploration \& Exploitation, vol. 38, no. 5, pp. 17061724, 2020.

[27] S. Q. Yang, M. Chen, H. W. Jing, K-F. Chen, and B. Meng, "A case study on large deformation failure mechanism of deep soft rock roadway in Xin'an coal mine, China," Engineering Geology, vol. 217, pp. 89-101, 2016.

[28] H. S. Jia, K. Pan, S. W. Liu, X. Dong, and J. Yu, "Deformation and failure law and control technology of coal bank in mining roadway," Journal of Mining and Safety Engineering, vol. 37, no. 5, pp. 689-697, 2020.

[29] J. B. Bai, T. Q. Xiao, and L. Li, "Differential method and its application for determining the distance between empty roof in roadway excavation," Journal of China Coal Society, vol. 36, no. 6, pp. 920-924, 2011. 